\title{
The Problem of Qualification in Determining the Applicable Law: Theoretical Approaches and Legislative Consolidation in the Republic of Kazakhstan
}

\author{
Maigul Nestayevna Abilova ${ }^{1}$ \\ ${ }^{1}$ Kazakh Humanities and Law University, Kazakhstan \\ Correspondence: Maigul Nestayevna Abilova, Korgalzhyn highway, 8, Astana, 010000, Kazakhstan.
}

Received: November 19, 2014 Accepted: December 15, 2014 Online Published: March 20, 2015

doi:10.5539/ass.v11n8p80 URL: http://dx.doi.org/10.5539/ass.v11n8p80

\begin{abstract}
The article is devoted to one of the most discussed issues in the theory of private international law - the question of qualification. Qualification is important in all branches of the law, as it is the basis for the subsequent administration of the law. The ultimate purpose of qualification is correct understanding and adequate application of a rule of law. In this article, the author expands on the importance of qualification in the private international law and in the process of determining the applicable law. The author analyzes basic doctrines of qualification that had been developed in the theory of private international law, and makes conclusions on the appropriateness of lex fori application at the stage of determining the applicable law, and application of lex causae at the stage of application of foreign law as a regulatory order. The article also analyzes legislative consolidation of legal qualification in the conflict of laws of the Republic of Kazakhstan. It should be noted that further presentation of the material mostly is based on the theoretical principles of private international law of the Republic of Kazakhstan (close to continental legal system) and on its legislative approaches.
\end{abstract}

Keywords: qualification in the private international law, autonomous qualification theory, lex causae qualification, lex fori qualification, determination of the applicable law, primary and secondary qualification, application of foreign law

\section{Introduction}

In the research we have widely used scientific methods such as analysis and systematization. Because the study was conducted in the field of private international law, one of the main methods that were used to draw our conclusions was the comparative legal method.

\section{Methods}

The problem of "qualification" is particularly pressing in the private international law. A judge faces the issue of qualification in all activities on administration of private international law and in determining the applicable law. At the stage of choosing the applicable law, qualification (namely, primary qualification) is extremely important because, although the rule of law governing the relations has not yet been chosen, the judge considers a specific established relations complicated by a foreign element and already uses certain concepts contained in the scope and connecting factor of a conflict rule, in the agreement of the parties, etc., significance of which must be established, and which must be evaluated. At the stage of application of law that directly regulates legal relations, qualification (namely secondary qualification) is important for understanding and further establishing the content of foreign law, if it is determined as applicable.

Occurrence of the qualification problem in the private international law theory is associated with the names of the German lawyer, Franz Kahn, who called this the "conflicts of qualifications" and the French lawyer, Etven Bartin, who spoke of "conflict of qualifications". They identified this problem in 1891 and 1897, respectively, independently of one another (Issad, 1989, p. 101; Luntz, 2002, p. 250). In English-American legal literature, the problem of qualification was first introduced by Professor Lorenzen in 1920. He linked the process of qualification with two main questions: 1) what does a judge do in carrying out qualification? 2) what is subject to qualification? He answers the questions posed in the following way: in the first case the court determines how to define one of legal concepts such as domicile, contract, etc.; in the second case, the answer is that qualification applies to a concept of a controversial nature, and after it is classified its definition becomes clear (Association of 
American Law Schools, p. 144). Different authors use the term "characterization", "qualification" and "qualification" when referring to this topic. However, "qualification" is more often referred to in civil law, while English law prefers "characterization" (Biryukova, pp. 63-66).

So, what is it - qualification in the private international law, and how is it relevant to determining the applicable law? According to R. Graveson the problem of classification arises from five main factors: 1. Different legal systems attach to the same legal term different meanings. 2. Different legal systems may contain ideas and conceptions completely unknown to one another. 3. Different legal systems assign to different branches of law problems which are of a common nature. 4. Different legal systems use different combinations of facts to constitute the factual basis for substantially similar legal concepts and rules. 5. Different legal systems use different methods to achieve the same result (Graveson, pp. 44-45). Speaking about the importance of qualification, M. Issad notes that qualification covers normal effect of the conflict law and the choice of applicable law. He believes qualification to be the definition of the legal nature of a fact or a transaction subject to applicable law and the conditions of its enforcement. This is one aspect of statutory construction (Issad, p. 100). For example, if we proceed from a generally accepted idea that relations in respect of immovables are governed by lex rei sitae, while relations in respect of movables are governed by the personal law of the owner, in this case the choice of applicable law will depend on whether a certain item deemed movable or immovable (Bendevskyi, p. 207), and further regulation of these relations will depend on qualification, i.e. definition and classification of the item as movable or immovable. But reducing qualification to interpretation only would not be entirely correct. Qualification represents not only interpretation, but also definition and assessment of legal concepts of the conflict rule and specific relations, which is important for implementation of the private international law rules, especially in the form of enforcement, which is only possible where the enforcer understands the genuine content of a contract terms or concepts of the conflict rule or the rule of substantive law. However, evaluation of legal concepts and specific relations should be conducted in the light of the legal concepts used in the scope and connecting factor of the conflict rule, practice and legislation of the forum, with a view to legitimate interests of the parties.

\section{Discussions}

Theory states that there are several most "sensitive" border fields, which often become the source of problems in the qualification of legal categories. These include the fields of inheritance law and law of obligations, substantive and procedural laws, family and property law. In addition, there is often a need to distinguish between the questions of form and content of a legal relation (Bendevskyi, p. 208). In the laws of different states, concepts used to express the scope and the connecting factors that often sound similar, may not coincide in meaning and content. This problem occurs because of differences in the laws of different states, in connection with which there is a conflict - the conflict of qualifications. An example of such a conflict would be the situation where, in accordance with the lex fori, a specific item is deemed movable, while under the laws of the state, to which the lex fori refers as the applicable law, this item is recognized to be immovable (Bendevskyi, p. 207), and there are many other examples.

Theoretical studies on this problem have led to the development of three major doctrines that reveal certain ways to implement qualification. These are the theories of:

- Autonomous qualification;

- Qualification by the law of the country which the legal relationship is most closely associated with (lex causae);

- Qualification by the law of the forum (lex fori).

The main question that one or another theory tries to give answer to is - according to the norms of which law and how should legal qualification be performed.

We will begin by considering the concept of autonomous qualification of the ideas of the conflict rule (i.e. qualification on the basis of generalization of concepts of different legal systems), which was proposed by the German legal scholar, E.Rabel in 1931 and found support in the doctrine (in particular, in the works of L. A. Luntz, T. Bendevsky) (Zvekov, p. 136; Galenskaya, p. 32; Bendevskyi, pp. 213-214).

Theory of autonomous qualification is in trying to interpret legal concepts, which conflict rule operates, autonomously, i.e. regardless of intrastate substantive law of that country. The author of this doctrine, E. Rabel, comes from the fact that one cannot attach the same significance to the legal concepts used in the conflict of laws rules that they have in the domestic substantive law of that state, because application of conflict rules is related to the necessity of appropriate qualification of legal institutions of different countries. Autonomous qualification 
proposed by Rabel must be obtained following the procedure of generalization of concepts from various intrastate systems. This generalization can only be the product of comparative law (Luntz, p. 256). One of supporters of autonomous qualification theory, M. M. Boguslavsky believes that the doctrine is based on the meaning of general legal concepts in the regulation of relations with the subjects of law of other legal systems. Any conflict rule is aimed at the recognition of effectiveness of an uncertain range of foreign legal systems and of subjective rights that emerged under their influence. Therefore, this rule can obviously be expressed only by the terms and concepts that are common in terms of their content for the respective legal systems. The sphere of effect of a conflict rule (its scope) must be expressed through "generalized" legal concepts that are common to different legal systems (Boguslavsky, p. 99).

However, in our opinion, the theory of autonomous or comparative legal qualification arouses fair criticism in the doctrine. For example, according to G. K. Dmitrieva, one cannot ignore the fact that the conflict rule, being national and legal in its nature, connects domestic law with the foreign law. The idea of creating conflict rules, consisting of legal concepts common to the law of different states, does not raise any objections, for this is the only way that they will be able to fulfill its function of selecting a competent rule of law well. But she asks the question: where are such "general" or "generalized" legal concepts found? G. Dmitrieva concludes that autonomous qualification as a way of interpreting the conflict rules cannot be the basis for the activities of the Court and other law enforcement agencies on the choice of law (Dmitrieva, pp. 136-138). Moreover, as emphasized in the theory, there is an extensive area of relations that for our purposes can be called the sphere of private and legal nature, where national and historical traditions have such a strong impact on the substantive law that talking about its unification in the foreseeable future seems very problematic (Shesteryakova, pp. 24-25).

According to N. P. Semyonov, who, by the way, supports this theory, unification of conflict rules through states entering into multilateral treaties with different legal systems was and remains rather problematic. He also notes that, in practice, there may be some difficulties in finding a "common denominator" (Semyonov, pp. 94-95). So, it should be noted that even proponents of this theory contradict themselves, ultimately recognizing failure and inability to implement the theory.

It is thought that no legal system of concepts that have a regulatory nature can exist in isolation from their sources. Accordingly, this legal system eventually should be reflected in a regulatory legal act. However, the entire course of development of conflict legal regulation leaves doubts that such an act would ever be adopted. In the absence of such an act there is still a danger of discrimination against certain states as a result of the fact that the concepts developed in these countries in the development of general concepts were not taken into account (Biryukova, pp. 117-118). Even if all countries had uniform conflict of law rules, the courts of different countries, guided by such rules that were uniform in their exterior form and applying the qualification of their own laws, would often came to unequal decisions on similar cases because legal qualification of similar sets of facts according to similar legislations in different countries may not be the same (because of differences in the concepts of substantive and procedural laws) (Luntz, p. 249). On top of that creation (development) of generalized concepts is hardly advisable - since rules of one country are created by the legislator of that state, they always reflect (even if there are points of unification and harmonization of law) peculiar characteristics of a particular legal system. The rules contain special understanding of certain legal phenomena. Therefore we could say that the presence of uniform rules could still lead to conflicts because of different approaches in the understanding of legal concepts, due to historical factors, mentality, etc.

Lex causae theory offers another version of qualification. Lex causae qualification was proposed by Despagne. In Italy, this concept was supported by Paccioni, and by Wolf in Germany (Issad, p. 103).

One of proponents of this theory, M. Wolf, criticizing the possibility of autonomous qualification and lex fori qualification, offers the following substantiation for lex causae qualification. He believes that it is preferable to proceed from the fact that every legal norm receives its qualification from the legal system to which it relates. French law qualifies French legal norms, while Italian law qualifies Italian rules, and English court, when investigating the applicability of French regulations must take French qualification into account. He believes that exploring the applicability of foreign law without reference to its qualification means not considering the foreign law as it is. According to him, foreign rule should be qualified on the basis of the entire foreign legal system (Wolf, pp. 166-180). According to Sh. M. Mengliev, under certain conditions, a fact can be qualified based on which state's legal system it is most closely associated with. If a court takes into account the qualification of concepts of law, determined by the conflict rules, the facts can be effectively resolved thereby and subjective rights will receive the desired protection. The author believes however that recognition and introduction of lex causae qualification theory will not solve the problem of conflict of qualification as a whole. However, in his 
opinion, this theory has essentially shaken the dominating theory of the law of the forum, taking its rightful place in the legislation (Mengliev, pp. 183-184).

With regard to this theory, G. K. Dmitrieva writes that this qualification method seems quite valuable and reasonable, as it actually aims at avoiding possible distortions of possibly applicable foreign law by qualification in terms of the concepts of own law, made before the choice of the applicable law. However, in practice, most often it is not possible to use this method because the problem is solved before it becomes known which law will be applied. Lex causae qualification does not solve the problem but brings it to a nonplus (Dmitrieva, pp. 134-135). In literature also is supported the view that if the relationship reviewed by court is largely associated with the law of a foreign country and must be governed by its rule of law, in order to perform such regulation, the relationship must be qualified according to the law of this foreign state. Objection to the feasibility of this doctrine is that qualification of the relationship impacts the choice of conflict rules. A relationship cannot be classified by lex causae, as it is yet unknown to what law the conflict rule will refer, and which rule of law will be lex causae (Tolstykh, pp. 91-92).

On the other hand, encouraging a court of one state in all cases to apply foreign law to qualify the conflict rules is hardly possible, since it is impossible to require that the court has the perfect knowledge of what is embedded in the legal concepts in that state. Fixing a qualification method by lege (lex) causae as the standard legal qualification method would imply the involvement of foreign law concepts in the qualification of a conflict rule, not in some cases but always (Biryukova, p. 111).

Thus, in our opinion, indeed, there is obviously a difficulty with lex causae qualification and it is hardly possible to practice such a method (on primary qualification stage). The question of qualification arises before the applicable law is determined; therefore, in this case the problem of qualification is solved before it is known which law will be applied. Sometimes a legal relationship is associated with several law orders; therefore, qualification based on lex causae may bring choosing the law to a nonplus. At this juncture, a sort of "magic circle" is created. However, we consider it fair to say that at the same time the lex causae theory is almost indispensable in secondary qualification.

Finally, qualification based on domestic law of the forum. Lex fori qualification was proposed in the writings of Kahn and Bartin. There are two main arguments produced in favor of qualification based on the law of the forum: a) this refers to determining the scope of a law of the forum. This is a problem of conflict rules interpretation. It would be unwise to assume that terms and concepts used by legislator are determined not by him but by a foreign legislator; b) qualification always precedes the effect of a conflict rule. At the time of qualification foreign law does not yet applied. Even if it determines the merits of dispute, it will do so only after the conflict rule of the forum country indicates its application, and it can only take effect after qualification. However, it should be noted that this argument also equally discourages the application of the law of forum - just like the foreign law it cannot be applied at the time of qualification. And there are two main objections against lege fori qualification: 1) it undermines attempts to unify private international law; 2) it is a legal uncertainty factor. While qualification must be made according to the law of the forum, at the time legal relationship is established parties will not know exactly which law it will be regulated by. And until proceedings are instituted, the legal relationship is sort of "hanging in the air" and determination of the applicable law is random (Issad, pp. 106-109).

A.N. Makarov, like most researchers, notes that from a theoretical point of view there is no doubt as to the fact that each qualification should be emphasized in the rule of law with which the legal relationship being classified is organically bound. But in the collision law the regulating rule of law is under the question itself: it is obvious that it is impossible to qualify a legal relationship based on an unknown rule of law, and that, consequently, such qualification no longer exists. All that is left to do is to qualify a legal relationship by lex fori, i.e. based on the domestic law of the judge. For all its theoretical imperfections, this option is the only practically feasible one. If we give it up, we will come to a dead end of expecting the "internationalization of all qualifications", i.e. expecting unification of civil rights across the globe (Makarov, p. 61; Peretersky \& Krylov, p. 51).

A representative of the common law doctrine, prof. Lorenzen, believes that qualification should be determined by the law of the forum country. This is how he explains his point of view: domestic law of the forum should be used as the basis because during primary qualification the court can only use the concepts of its domestic law. Although this theory cannot sustain the case where domestic law is not aware of any institutes and rules of foreign law. But Lorenzen believes that primary qualification should be carried out by the law of the forum, and the secondary one - based on the law that governs the relevant relations. At the first stage we apply the 
qualification of the law of the forum country, because only a judge by way of analysis must determine the true content of circumstances of the case (Association of American Law Schools, pp. 150-152).

V. L. Tolstykh argues against lex fori that such qualification leads to weak relations. In cases where one goes to court of one state, the relationship will be classified in one way, in case of appeal to a court of another state, it will be classified otherwise. If the relationship gravitates towards a foreign state, it needs to be classified in accordance with the foreign law, and not with the law of the forum (Tolstykh, pp. 171-172). The main disadvantage is that the lege fori qualification provides no solutions when it is necessary to qualify a legal institute that domestic law is not familiar with (Biryukova, p. 108). In our opinion literature correctly notes that the lex fori largely ceased to be a means of denying the applicability of foreign law, but it is turning into something that can be called "the last resort" of law enforcer in difficult conflict of law situations (Zhiltsov \& Muranov, p. 39).

According to Sh. M. Mengliev, if we base on the interpretation and application of the domestic legal system by the law of court, one would have to ignore the position of the conflict rules of the national law that refer to the foreign law. As a result, a factual circumstance will not receive proper legal qualification, conflict rules will not reach the goal and dispute will remain unresolved on the merits. Lege fori cannot be considered a universal form of legal qualification, but the rule of legal qualification by the law of the court is the consolidation of the most applicable method of qualification conflict corresponding to the international practices. Such rules seem eminently fair, for the court is related to the conflict rules of its own country and operates the legal concepts incorporated in the national law (Mengliev, pp. 180-186).

\section{Results}

We believe that it should be clearly understood that the qualification in the process of determining the applicable law is not a one-step phenomenon. It is believed that the problem of qualification and ways of addressing it exist only at the stage of the choice of law in the application of own conflict rules and after the competent legal order is chosen, these problems should not occur (Dmitrieva, p. 141). However, to us this view seems questionable. Even when the applicable law is determined, especially when it is foreign, the question of qualification still exists, since in any case the court has to deal with legal categories in need of interpretation, whether these are legal categories of the forum country or, especially, foreign law. Sh. M. Mengliev indicates that the main requirement is the application of the foreign law as it is applied in its homeland. This means that the court cannot interpret foreign rules of law in the way it interprets the laws of its own country. The court sort of takes the place of the foreign court (Mengliev, p. 208). Thus, in our view, we should distinguish qualification at the stage of determining the applicable law, i.e., primary qualification when: 1) qualification covers the scope of a conflict rule and its correlation with a specific relation; 2) qualification of the relationship is considered through the lens of conflict rules and legal practice in the country of the court; 3) qualification (interpretation) of connecting factor is performed, by which the applicable law is further determined. Secondary qualification must also be distinguished, it is carried out at the stage of application of the rule of law that has already been chosen, which will govern these relationships; this may be the law of the forum or the foreign law. In the latter case secondary qualification is closely associated with the establishment of the content of foreign law and the direct application of foreign law.

In our view, the most expedient method of primary qualification is qualification by the law of the forum, i.e. lex fori method. A conflict rule is a rule of the national law, and therefore it uses the concepts of domestic law. Legal terms that make up the scope and the connecting factor of conflict rules have the same content as that of the substantive private law of their state. A legislator, creating a conflict rule, uses the concepts of their law, not foreign law. Likewise, the court, when performing primary qualification for the purposes of determining the applicable law should only be based on definitions of its domestic law. However, in all fairness, we will note that in this approach the content of foreign law can be completely ignored and distorted, unless it is determined to be applicable.

But, as is correctly noted, despite all the shortcomings and deficiencies of this concept, it is nevertheless often the only possible, because the need for lex fori qualification arises when it is not yet known, which law will govern the disputed legal relation (Dmitrieva, p. 134) and if there is no way out, then as ultima ratio (i.e. in extreme case) only lex fori remains, however not because of the assumption that the foreign law coincides with lex fori, but just because of necessity to find a way out from the situation (Raape, p. 131). Therefore, efficiency of lex fori qualification is due to the fact that at the time of primary qualification the foreign law cannot yet be applied because it has not yet been chosen. Even if it will address merits of a dispute, it will only do so after a 
conflict rule of the forum country indicates its application; however, it can only come into effect after qualification.

Regarding the other two of the above mentioned theories we will say the following. The rules of law arise in each individual state and accordingly are given their specificity. Initially, each state uses its own terminology, and gives a particular meaning to a legal concept. Autonomous qualification theory advocates for generalization of concepts and unification. Not having anything against the reasonable limits of unification, it should be noted that any national legal system tends to change and evolve, and in this case, given the complexity of unification process, we can assume in advance that, being established on the basis of generalized concepts contained in national legislations once, it is, however, unlikely to undergo further modification. Who will create legal rules by generalization and will they be at all endowed with a single legality and legal effect? The judges involved in the process of determining the applicable law, cannot be engaged in a process of generalization of legal concepts.

Thus, it can be argued that today real practical implementation of provisions of being discussed doctrine is not possible. The concept of autonomous qualification might remain only a concept for a long time. In our opinion, the trouble with implementation of theses of this theory is the inevitability and necessity of legal concepts generalization as this can only be the result of a scientific comparative legal studies. It appears that the generalized concepts, obtained in the comparative analysis, can certainly play a positive part, for example in terms of adopting positive experience from law enforcers in other countries, but it is unlikely that they will be obligatory for all.

Court and arbitration are directly engaged in law enforcement, and for obvious reasons they cannot develop generalized concepts and conduct a comparative analysis of the concepts found in different legal systems. On this occasion Sh. M. Mengliev correctly notes that the court cannot determine the "generalized" concepts for different legal systems for the simple reason that it is not its task (Mengliev, p. 185). Moreover, interpretation performed by a judge (even if it is assumed that the judge has taken up the implementation of autonomous qualification theory and developed general concepts) is not binding.

However, despite all of the above-mentioned drawbacks, the concept of autonomous qualification can be used successfully in the international agreements, which directly establish qualification rules. In such cases, as a rule, the states that are parties to an agreement, determine the content of concepts and terms that they will use in the future in the preamble of the agreement or in its general provisions.

As for lex causae qualification theory, it is obvious to us that this theory is ineffective at the stage of primary qualification, at the stage of determining the applicable law, because at this stage the judge often does not yet know the law of what state will be determined as applicable in regulation of certain relations. Lex causae qualification at the stage of primary qualification is risky; it can lead to a dead-end situation. If however we speak about secondary qualification, i.e. qualification carried out after application of a conflict rule, further qualification should be based on the legal system to which the conflict rule refers. And this is where it is possible to apply lex causae qualification theory.

The question of regulation the determining of applicable law, apart from enforcer's approach, also depends on the legislative approach of a particular state. In paragraph 1 Article 1085 of the Civil Code of the Republic of Kazakhstan it says that the qualification of legal concepts (legal qualification) by the court is based on their interpretation in accordance with the law of the forum country, unless otherwise provided by legislation. Further, paragraph 2 of the same article stipulates that if legal concepts are unknown to the law of the forum or are known by another name or with a different content and cannot be identified through interpretation by the law of the forum country, foreign law may also be applied in the qualification of legal concepts (legal qualification).

Thus, the Civil Code of the Republic of Kazakhstan relies upon lex fori theory. Along with that the Civil Code of the Republic of Kazakhstan provides qualification for individual concepts also by lex causae. Thus, for example, paragraph 1 of Article 1106 of Civil Code specifies that the statute of limitations is determined by the law of the country, applied to regulate the corresponding relations; paragraph 2 of Article 1107 establishes that whether the property is considered an immovable or movable, as well as other legal qualification of the property is determined by the law of the country where the property is located (this may be the law of Kazakhstan, or the law of any other state). This "disobedience" to the law of the forum can be explained by the specifics of the regulated object.

However, it should be noted that our legislation, fixing the general lex fori rule, has no clear boundaries between primary and secondary qualifications. In the result of the analysis of this Article we can make a conclusion, that Article 1085 of the Civil Code of the Republic of Kazakhstan refers to the primary qualification, i.e. one that takes place at the time of the choice of the applicable law. Paragraph two of this Article could probably be 
deemed as exhibiting flexibility in the regulation of this issue, because it establishes the possibility of applying the lex causae principle. However, in our opinion, the second paragraph of the analyzed Article could be summarized as follows: "if legal concepts are unknown to the law of the forum country, or are known by other names, or other content, and cannot be identified through interpretation by the law of the forum country, or when foreign law is determined as applicable, foreign law may also be applied in the qualification of legal concepts". Thus, the legislation could define the scope of the two stages in the application of the rules of private international law, and determine the applicable law of qualification. Two stages of qualification are subject to distinction because they have different focus. If a conflict rule refers to the foreign law as applicable, any further qualification, in our view, should only be based on the qualification by the law of this legal system. And this important point could be formalized in legislation.

\section{Conclusion}

Thus, we define qualification as a definition, interpretation, categorization and evaluation of the concepts used in the conflict of laws rules and the correlation between the concepts and terms of agreements of the parties and the facts of the case.

It should be kept in mind that the problem of qualification can arise when different countries use the same conflict rules, and, furthermore, the same concepts. But even the presence of the same rules does not lead to the same choice of the applicable law. Due to the differences in the meanings assigned by different states to the concepts used, the court of each state can interpret a rule in a particular way. Thus, resolution of a case and qualification will ultimately depend on the state where a particular case is being considered. Due to such "unequal" approaches of enforcers from different states to the question of qualification, the presence of general categories and legal concepts in the rules of the states, offered by proponents of the autonomous qualification theory will not save the situation. Qualification problems could not be avoided, even if all countries had conflict rules, which contain the same scope and connecting factors. As for lex causae qualification, it is obvious that it would be impossible to interpret a rule and relate the facts of the case to the rules of a foreign law that is not yet chosen.

But, without prejudice to the concepts discussed above, we would like to note that lex fori qualification by the law of the forum, even with all the above mentioned disadvantages, seems to be the most rational at the stage of choice of the applicable law. At the same time, both autonomous qualification concept and lex causae qualification theory may also find the application: the former - in the international treaty practice, and the latter at the stage of secondary qualification.

In conclusion, we would like to note that the present work is not intended to cover all the existing problematic issues of qualification, and generally there are still numerous problems of private international law, which require a comprehensive study for the further development of private international law fundamentals in the Republic of Kazakhstan. The results obtained presume further research of other aspects of the problem.

\section{References}

Bendevskiy, T. (2005). In E. A. Suhanov (Ed.), Private International Law: Textbook. Moscow, Statute.

Biryukova, N. S. (2007). The problem of legal qualification in private international law. Unpublished master's thesis. Moscow, Moscow State Law Academy.

Boguslavsky, M. M. (2002). Private International Law (4th ed., revised and extended). Moscow, Yurist.

Dmitrieva, G. K. (2001). Private International Law: Textbook. Moscow.

Galenskaya, L. N. (1983). Private International Law: Textbook. Leningrad, LSU.

Graveson, R. H. (1974). Conflict of laws. Private International Law (7th ed.). London, Sweet\&Maxwell.

Issad, M. (1989). Private International Law. Moscow, Progress.

Luntz, L. A. (2002). Private International Law Course (Vol. 3). Moscow, Spark.

Makarov, A. N. (1924). Basic Principles of Private International Law. Moscow.

Makovsky, A. L., Zhiltsov, A. N., \& Muranov, A. I. (2000). Private International Law: Foreign Legislation. Moscow, Statute.

Maurice, S. G. (1956). Selected readings on Conflict of Laws. Compiled by the Committees on Selected articles on Conflict of Laws of the Association of American Law Schools. St. Paul, Minn. By West Publishing.

Mengliev, Sh. M. (2002). Private International Law (Part 1). Dushanbe, Devashtich. 
Peretersky, I. S., \& Krylov, S. B. (1959). Private International Law (2nd ed., revised and extended). Moscow, Legal Literature.

Raape, L. (1960). Private International Law. Moscow, Foreign Literature Publishing House.

Semenov, N. P. (1990). On feasibility of drafting a law on private international law. Soviet State and Law, 1, 98-105.

Shesteryakova, I. V. (2000). Conflict labor issues under the Private International Law. Unpublished master's thesis. Saratov, Saratov State Academy of Law.

Tolstyh, V. L. (2004). Private International Law: Conflict regulation. S-Pbg.

Tolstykh, V. L. (2002). Conflict regulation in private international law: Problems of interpretation and application of Section VII, Part three of the Civil Code of the Russian Federation. Moscow, Spark.

Wolf, M. (1948). Private International Law. Moscow, State legal publishers of foreign literature.

Zvekov, V. P. (2000). Private International Law. Series of lectures. Moscow, NORMA.

\section{Copyrights}

Copyright for this article is retained by the author(s), with first publication rights granted to the journal.

This is an open-access article distributed under the terms and conditions of the Creative Commons Attribution license (http://creativecommons.org/licenses/by/3.0/). 